\title{
First record of the Cretaceous family Mimarachnidae (Homoptera: Fulgoroidea) in amber
}

\author{
Первая находка мелового семейства Mimarachnidae \\ (Homoptera: Fulgoroidea) в янтаре
}

\author{
Dmitry E. Shcherbakov \\ A.E. Щербаков
}

\begin{abstract}
A. A. Borissiak Paleontological Institute, Russian Academy of Sciences, Moscow, Russia. E-mail: dshh@narod.ru Палеонтологический институт им. А.А. Борисяка РАН, Москва, Россия.
\end{abstract}

KEY WORDS: Mimarachnidae, Fulgoroidea, Auchenorrhyncha, planthoppers, sensory pits, phylogeny, fossil, Cretaceous, Burmese amber.

КЛЮЧЕВЫЕ СЛОВА: Mimarachnidae, Fulgoroidea, Auchenorrhyncha, носатки, сенсорные ямки, филогения, ископаемые, меловой период, бирманский янтарь.

ABSTRACT. Burmissus raunoi gen. et sp.n. is described from mid-Cretaceous Burmese amber. It is the first record of the Cretaceous planthopper family Mimarachnidae in amber. The $10-\mathrm{mm}$ adult has numerous minute sensory pits, resembling punctation, on the head and thoracic nota, different number of teeth in the left and right hind leg pectens, and an extremely long rostrum projecting beyond the tips of the tegmina and suggesting that the insect had lived on tree bark.

РЕЗЮМЕ. Из среднемелового бирманского янтаря описан Burmissus raunoi gen. et sp.n. Это первая находка мелового семейства носаток Mimarachnidae в янтаре. У 10-миллиметрового имаго многочисленные мелкие сенсорные ямки покрывают подобно пунктировке голову и грудные тергиты, разное число зубцов в гребнях на вершинах члеников левой и правой задних ног, а необычайно длинный хоботок выступает за вершины передних крыльев вероятно, насекомое обитало на коре деревьев.

Ten years ago, two peculiar extinct planthopper families, Perforissidae and Mimarachnidae, have been described from the Cretaceous [Shcherbakov, 2007a, b]. Perforissidae have been reported from Cretaceous ambers and sedimentary rocks of Eurasia (including Lebanon) and both Americas, i.e. both Laurasia and Gondwana [Peñalver, Szwedo, 2010; Szwedo et al., 2013; Petrulevičius et al., 2014; Zhang et al., 2017]. In contrast, Mimarachnidae have been known only from the Eurasian rock fossils [Szwedo, 2008; Szwedo, Ansorge, 2015]. A new mimarachnid discovered in Burmese amber belongs to a new genus and species described below. It is the first amber record of Mimarachnidae.

Being dissimilar in many respects, Perforissidae and Mimarachnidae share some traits in common: the tegmen narrowed, especially in the costal area, termi- nal vein forks reduced, the clavus open, and nymphal sensory pits retained in the adults [Shcherbakov, 2007a, b]. Destabilization and underdevelopment of the hind leg armature, reported in Perforissidae [Shcherbakov, 2007a], occur in Mimarachnidae as well: in Burmissus gen.n., the teeth number in the tibial and tarsal pectens varies within one individual and the hind tibial pecten is asetigerous, in contrast to other mimarachnids. The double median carina on the mesonotum in Mimarachnidae resembles the immature condition (carinae separated by the ecdysial line) and likely represents another nymphal character retained by the adult. All these 'regressive' characters indicate the paedomorphic (neotenous) nature of perforissids and mimarachnids.

The body cuticle of nymphs of Fulgoroidea (except for Tettigometridae and Hypochtonellidae) bears sensory pits [Bräunig et al., 2012] — specialized sensillae thought to be hygroreceptors [Šulc, 1928]. Sensory pits persist at the adult stage in some planthopper taxa [Shcherbakov, 2007a], and this is often the case in extreme xerophiles or hygrophiles [A.F. Emeljanov, pers. comm.]. In nearly all fulgoroid families (including Perforissidae) sensory pits form a pattern of distinct rows and groups associated with the system of carinae. Mimarachnidae demonstrate a more primitive condition: their very small sensory pits superficially resemble coarse punctures and cover the thoracic nota more or less evenly. Homologues of fulgoroid sensory pits are setigerous pits occurring in Aphrophoridae and primitive Membracoidea such as Ledrinae, Ulopinae and Stegaspidinae [Emeljanov, 2001; Shcherbakov, 2011].

The extremely long and slender rostrum of Burmissus gen.n., projecting like a cocktail straw beyond the apices of folded tegmina, suggests feeding on trees with thick and rough bark. An extremely long rostrum is 
characteristic of aphids [Heie, Azar, 2000] and other plant-feeding Hemiptera living on rough trunks and large branches of trees. Such rostra are common among Mesozoic Auchenorrhyncha (e.g. Palaeontinidae, Tettigarctidae, Fulgoridiidae) indicating that feeding on trunks and large branches was then more widespread than nowadays [Shcherbakov, Popov, 2002]. The Burmese amber tree is similar to Agathis (Araucariaceae), and the amber forest was a tropical-subtropical rainforest resembling the kauri forest in Northern New Zealand [Poinar et al., 2007; Poinar, Buckley, 2008].

The Burmese amber contains the richest insect fauna including 284 families, 449 genera, and 524 species already described [Ross, 2017]. It is collected from mines in the Hukawng Valley, Kachin State, Myanmar. The amber-containing rock has been dated early Cenomanian [Shi et al., 2012], but the amber shows traces of re-deposition [Ross, 2015] and can be older (Albian) [Zhang et al., 2018].

The holotype of the new species is deposited in A. A. Borissiak Paleontological Institute, Russian Academy of Sciences, Moscow (PIN). Photographs were taken using a Leica M165C stereomicroscope with a Leica DFC425 digital camera and processed with Helicon Focus 5.1.

Family Mimarachnidae Shcherbakov, 2007

REVISED DIAGNOSIS. Small to rather large (9-25 $\mathrm{mm}$ ), elongate planthoppers with poor vein branching and meshwork of crossveins, superficially resembling some Fulgoridae. Tegmen: R deeply forked; RP more prominently raised than RA; M with terminal fork or 3-branched; arculus (basal $m-c u$ ) weak or indistinct; $\mathrm{CuA} 1$ and $\mathrm{CuA} 2$ simple; clavus open (claval suture not entering margin); stalk of claval $\mathrm{Y}$ vein $(\mathrm{Pcu}+1 \mathrm{~A})$ joining either commissural margin or claval suture; sometimes with narrow marginal membrane developed beyond claval apex. Usually tegmen obliquely truncate apically, with RA simple, RP forked near apex, CuA fork deep, both costal area and $\mathrm{R}$ fork narrow. Hindwing with $\mathrm{R}$ and $\mathrm{CuA}$ forked, $\mathrm{M}$ simple. Head neither produced nor shortened; lateral ocelli present; eumetope 3- or 5-carinate (for planthopper cranium nomenclature, see Anufriev, Emeljanov [1988]), together with clypeus evenly convex in profile; rostrum long to very long. Mesonotum with 4 or 6 carinae: a pair of close-set median carinae, anteriorly converging lateral carinae, and sometimes with short intermediate carinae. Head, pro-, and mesonotum with numerous small sensory pits. Legs more or less elongate; hind tibia without lateral teeth; apical pecten of hind tibia of 4-8 teeth, sometimes setigerous; metatarsal pectens of 4-10 teeth. Ovipositor apparently ensiform.

COMPOSITION. Mimarachne Shcherbakov, 2007 and Saltissus Shcherbakov, 2007 from Late Neocomian of Transbaikalia; Nipponoridium Szwedo, 2008 from Aptian of Japan; Mimamontsecia Szwedo et Ansorge, 2015 and Chalicoridulum Szwedo et Ansorge, 2015 from Barremian of Spain; Burmissus gen.n. from Albian-Cenomanian of Myanmar.

DISTRIBUTION. Europe and Asia; Early and Late Cretaceous (Early Neocomian to Turonian); unpublished records from Early Neocomian of Transbaikalia, Aptian of Mongolia, Albian of Khabarovsk Region and Turonian of Kazakhstan [Shcherbakov, 2007b].

\section{Burmissus Shcherbakov,gen.n.}

TYPE SPECIES Burmissus raunoi sp.n.

DIAGNOSIS. Rather small (tegmen ca. $8 \mathrm{~mm}$ long), slightly dorsoventrally depressed, looking somewhat leafhopper-like, with tegmina shallowly tectiform in repose. Tegmen broadest before midlength; costal margin arched near base; costal area narrow distally; R fork narrow. Hind wing with subequal $\mathrm{R}$ and $\mathrm{CuA}$ forks, and few crossveins near apex. Rostrum extremely long, slender, reaching beyond tips of tegmina. Pro- and mesonotum with doubled median carina. Pronotum transverse with horizontal paranota, sharp posterior angles, and shallowly $\mathrm{W}$-shaped posterior margin. Mesonotum 6-carinate, with short intermediate carinae. Legs slender; hind tibia and first two tarsomeres with $4-5,5$, and 4-5 asetigerous apical teeth, correspondingly.

COMPOSITION. Type species.

COMPARISON. Distinct from other genera in the tegminal venation, longer rostrum, shape of pronotum, and presence of intermediate mesonotal carinae (as far as known, in other mimarachnids the pronotum is more strongly incised posteriorly and the mesonotum lacks intermediate carinae). Distinct from Nipponoridium in much smaller size, and deeper CuA fork and few crossveins in the hind wings (in Nipponoridium, known from a hind wing, the $\mathrm{CuA}$ fork is short and crossveins are abundant). Similar to Chalicoridulum in the small size and the tegmen broadest before its midlength, but in the latter the $\mathrm{R}$ fork and the distal part of the costal area are not narrowed.

ETYMOLOGY. From Burma and genus Issus Fabricius, 1803; gender masculine.

\section{Burmissus raunoi Shcherbakov,sp.n. \\ Figs 1-10.}

MATERIAL. Holotype male PIN 5608/2 (slightly gnawed by some scavenger: thoracic venter, left wings and fore legs damaged, mid legs torn away; tips of rostrum and right tegmen polished away) - Burmese amber, Hukawng Valley, Kachin State, Myanmar; mid-Cretaceous (Albian-Cenomanian).

DESCRIPTION. Body with wings $10.5 \mathrm{~mm}$ long. Tegmen $7.9 \mathrm{~mm}$ long, $2.2 \mathrm{~mm}$ wide, broadest near base, costal margin arched there; precostal carina rather narrow, horizontal; R forked at basal $1 / 4$ of tegmen; $\mathrm{R}$ fork narrow; RA and RP simple; RP more prominently raised than RA; RP area about tegmen midlength wider than either $\mathrm{C}$ area or $\mathrm{M}$ area; $\mathrm{M}$ apically 2- (left) or 3-branched (right tegmen); $\mathrm{CuA}$ forked just beyond junction of arms of $\mathrm{Y}$-vein; $\mathrm{CuA}$ stem and $\mathrm{CuA} 2$ basally very close to claval suture; $\mathrm{CuA} 2$ base weak; Pcu Sshaped; arms of Y-vein longer than its stalk, their junction much nearer to commissural margin than to claval suture; stalk of Y-vein joining commissural margin; beyond this point, $\mathrm{CuP}$ area membraneous, narrow corrugate marginal membrane present; commissural carina absent. Tegmen bare, dark-marbled, with four oblique dark bands and eight dark streaks near costal margin; veins, numerous crossveins and their blind branchlets pale; four ocellar spots pale, accentuated with adjacent dark crescents (one large semilunar spot across arms of Y-vein and three smaller spots nearby-one near claval apex and two in $\mathrm{M}$ area); with few sensory pits along veins near base. Hindwing fuscous with veins dark, $\mathrm{R}$ fork slightly distal to CuA fork, Pcu deeply S-shaped distally, and few distal crossveins, including long strong crossveins in $\mathrm{CuP}$ area and very short double cell rows near apical margin. Head with eyes 1,9 mm wide, twice as wide as long, x1.5 narrower than pronotum. Coryphe transverse, pentagonal, $\mathrm{x} 1.5$ as wide as long, depressed, with raised borders, without distinct median carina. Acrometope shaped as two triangular 


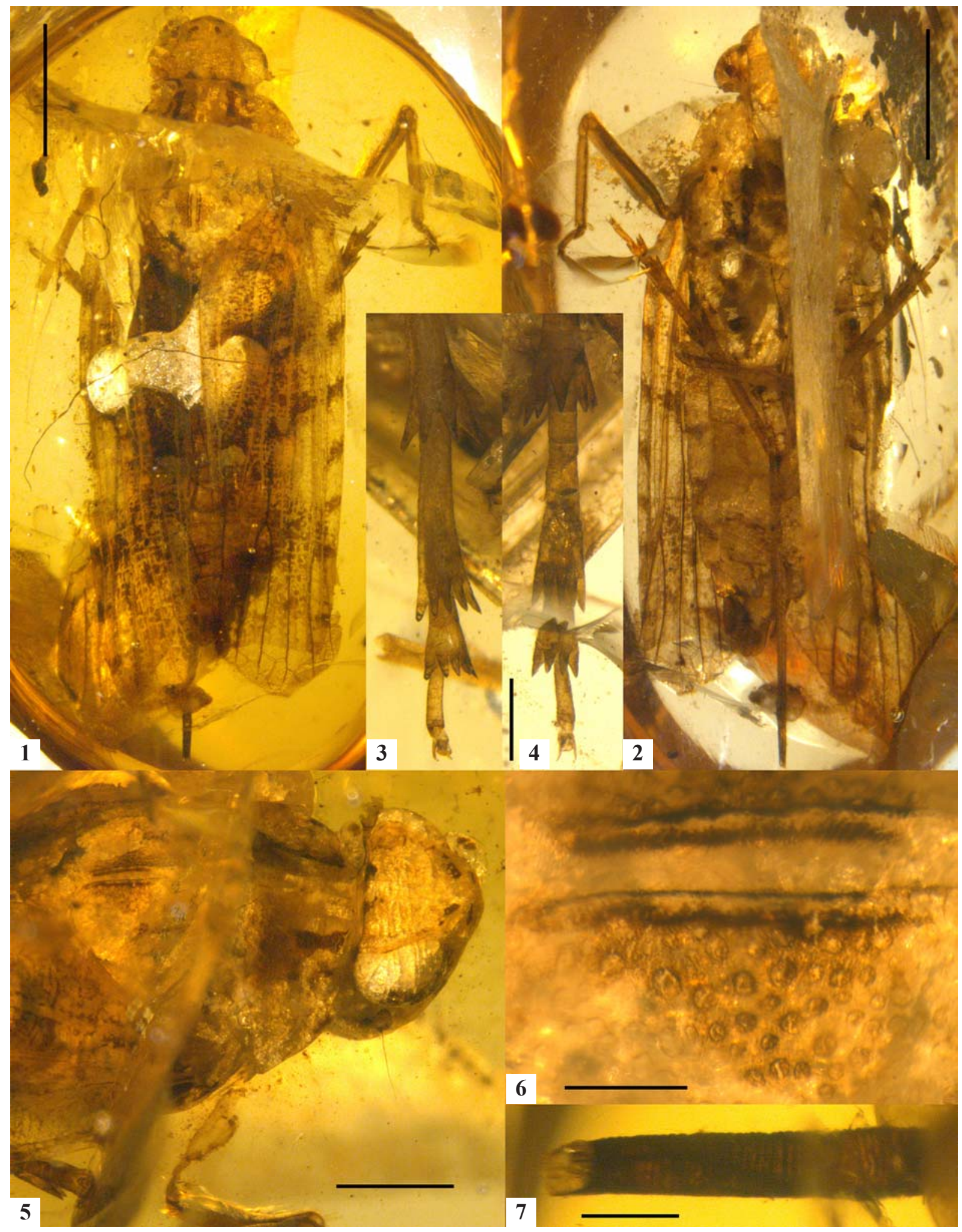

Figs 1-7. Burmissus raunoi gen. et sp.n., holotype PIN, Burmese amber: 1 - habitus, dorsal view; 2 - habitus, ventral view; 3 - distal part of right hind leg; 4 - distal part of left hind leg; 5 - head and pronotum, laterodorsal view; 6 - sensory pits near median carinae of mesonotum; $7-$ tip of rostrum, dorsal view. Scale bars: $1-2-2 \mathrm{~mm} ; 3-4-0.5 \mathrm{~mm} ; 5-1 \mathrm{~mm} ; 6-7-0.2 \mathrm{~mm}$.

Рис. 1-7. Burmissus raunoi gen. et sp.n., голотип ПИН, бирманский янтарь: 1 - общий вид сверху; 2 - общий вид снизу; 3 дистальная часть правой задней ноги; 4 - дистальная часть левой задней ноги; 5 - голова и переднеспинка сверху-сбоку; 6 сенсорные ямки у срединных килей среднеспинки; 7 - вершина хоботка сверху. Масштаб: 1-2 -2 мм; 3-4 - 0.5 мм; $5-1$ мм; $6-7-0.2$ мм. 


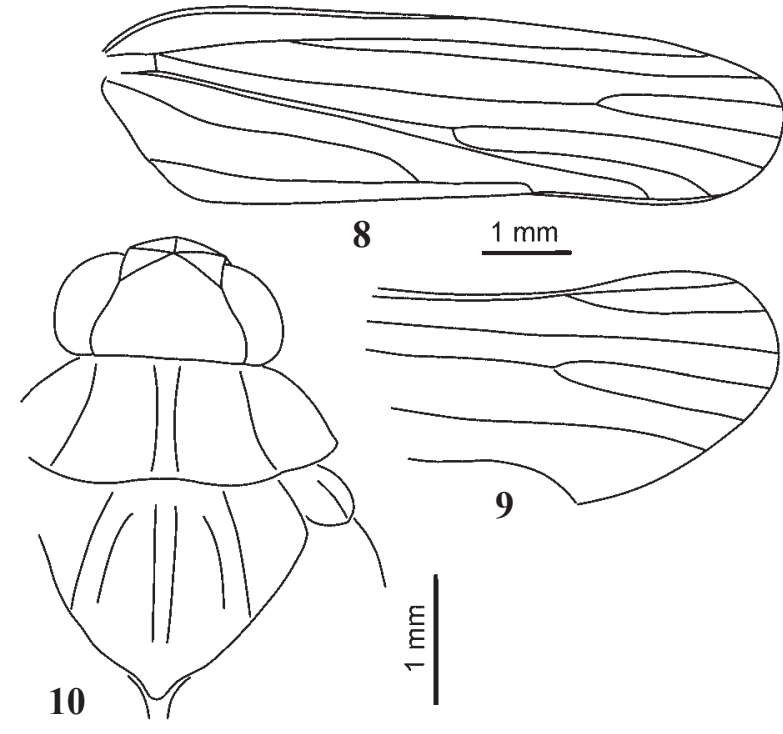

Figs 8-10. Burmissus raunoi gen. et sp.n., holotype PIN, Burmese amber: $8-9$ - venation: 8 - forewing; 9 - distal part of hind wing; 10 - head, pro- and mesonotum, dorsal view.

Рис. 8-10. Burmissus raunoi gen. et sp.n., голотип ПИН, бирманский янтарь: 8-9 -жилкование: 8 - переднее крыло; 9 - дистальная часть заднего крыла; 10 - голова, передне- и среднеспинка сверху.

areolets touching with their apices. Eumetope + clypeus broadest below antennae, with low median and intermediate carinae and strong lateral carinae. Antennae small, unmodified; scape pale, subconical; pedicel fuscous, subpyriform. Rostrum $8.5 \mathrm{~mm}$ long, slender, with apical $1 / 6$ dark and transversely striated on posterior (upper) side. Pronotum 2.8 $\mathrm{mm}$ wide, transverse, $\mathrm{x} 2.7$ as wide as long; disc raised, saddle-like, with two strong median carinae (other carinae not evident); paranota subhorizontal, their lateral margins strongly diverging backwards; posterolateral angles sharp, posterior margin arched, with median concavity. Mesonotum convex; median carinae high, lateral and shorter intermediate carinae converging anteriorly; mesoscutellum raised, area anterior to it depressed. Coryphe, pro- and mesonotum covered with small sensory pits (better visible on dark areas). Legs long and slender, not flattened; tibiae quadrilateral with short strong setae along their edges. Hind tibia + tarsus 4.5 $\mathrm{mm}$ long; 1st tarsomere longer than 2 nd and 3rd combined; apical pectens with 4 or 5 large asetigerous teeth: in right leg of holotype, both tarsal pectens with 5 teeth and tibial pecten with 4 teeth $(2+2$ with narrow diastema); in left leg, 2 nd tarsal with 4 teeth and two other pectens with 5 teeth. Claws small, slender; arolium well developed. Abdomen elongate, not reaching tips of tegmina, broadest at 4th segment, weakly tapered to apex; laterotergites visible in ventral aspect; genitalia small. Body pale with paired dark markings on head, pro- and mesonotum; legs fuscous.

ETYMOLOGY. The species is dedicated to Rauno E. Linnavuori, an expert in the taxonomy of Hemiptera, on the occasion of his 90 th birthday.

ACKNOWLEDGEMENTS. I am deeply indebted to Alexander Emeljanov (Zoological Institute RAS) and Roman Rakitov (PIN) for valuable suggestions and comments on the manuscript. The study was supported by the RFBR project 16-04-01498.

\section{References}

Anufriev G.A., Emeljanov A.F. 1988. [Suborder Cicadinea(Auchenorrhyncha)] // Opredelitel' vasekomykh Dal'nego Vostoka SSSR. Vladivostok. Vol.2. P.12-495 [in Russian].

Bräunig P., Krumpholz K., Baumgartner W. 2012. Sensory pits Enigmatic sense organs of the nymphs of the planthopper Issus coleoptratus (Auchenorrhyncha, Fulgoromorpha) // Arthropod Struct. Dev. Vol.41. P.443-458.

Emeljanov A.F. 2001. Larval characters and their ontogenetic development in Fulgoroidea (Homoptera, Cicadina) // Zoosyst. Ross. Vol.9 (for 2000). P.101-121.

Heie O.E., Azar D. 2000. Two new species of aphids found in Lebanese amber and a revision of the family Tajmyraphididae Kononova, 1975 (Hemiptera: Sternorrhyncha) // Ann. Entomol. Soc. Am. Vol.93. P.1222-1225.

Peñalver E., Szwedo J. 2010. Perforissidae (Hemiptera: Fulgoroidea) from the Lower Cretaceous San Just amber (Eastern Spain) // Alavesia. Vol.3. P.97-103.

Petrulevičius J.F., Varela A.N., Iglesias A., Zamuner A.B., Poiré D.G. 2014. First Cenomanian record of insects in the Southern Hemisphere, with Perforissidae (Fulgoroidea) and Cupedidae (Coleoptera) from Southern Patagonia, Argentina // Cretaceous Res. Vol.51. P.174-185.

Poinar G.O., Buckley R. 2008. Cretacifilix fungiformis gen. and sp. nov., an eupolypod fern (Polypodiales) in Early Cretaceous Burmese amber // J. Bot. Res. Inst. Texas. Vol.2. P.1175-1182.

Poinar G., Lambert J.B., Wu Y. 2007. Araucarian source of fossiliferous Burmese amber: spectroscopic and anatomical evidence // J. Bot. Res. Inst. Texas. Vol.1. P.449-455.

Ross A. 2015. Insects in Burmese amber // Entomologentagung 0205.03.2015 Frankfurt/M. Programm und Abstracts. Frankfurt/ Main: DGaaE. P.72.

Ross A.J. 2017. Burmese (Myanmar) amber taxa, on-line checklist v.2017.3. 83 pp. https://www.nms.ac.uk/media/1155405/burmese-amber-taxa-v2017_3.pdf.

Shcherbakov D.E. 2007a. Ān extraordinary new family of Cretaceous planthoppers (Homoptera: Fulgoroidea) // Russ. Entomol. J. Vol.16. P.139-154.

Shcherbakov D.E. 2007b. Mesozoic spider mimics - Cretaceous Mimarachnidae fam.n. (Homoptera: Fulgoroidea) // Russ. Entomol. J. Vol.16. P.259-264.

Shcherbakov D.E. 2011. New and little-known families of Hemiptera Cicadomorpha from the Triassic of Central Asia - early analogs of treehoppers and planthoppers // Zootaxa. Vol.2836. P.1-26.

Shcherbakov D.E., Popov Yu.A. 2002. Order Hemiptera Linné, 1758. The bugs, cicadas, plantlice, scale insects, etc. // Rasnitsyn A.P., Quicke D.L.J. (eds.). History of Insects. Dordrecht: Kluwer. P.143-157.

Shi G., Grimaldi D.A., Harlow G.E.,Wang J., Wang J., Yang M., Lei W., Li Q., Li X. 2012. Age constraint on Burmese amber based on U-Pb dating of zircons // Cretaceous Res. Vol.37. P.155-163.

Šulc K. 1928. Die Wachsdrüsen und ihre Produkte bei den Larven der Cixiinen (Homoptera) // Biol. Spisy Vysoké Školy Zvěrol., Brno. Vol.7. P.149-180.

Szwedo J. 2008. Distributional and palaeoecological pattern of the Lower Cretaceous Mimarachnidae (Hemiptera: Fulgoromorpha) // Entomol. Gener. Vol.31. P.231-242.

Szwedo J., Azar D., Nohra Y. 2013. First record of Perforissidae from the Early Cretaceous Lebanese amber (Hemiptera: Fulgoromorpha: Fulgoroidea) // Insect Evolution in an Amberiferous and Stone Alphabet. Proceedings of the 6th International Congress on Fossil Insects, Arthropods and Amber. Leiden-Boston: Brill. P.145-163.

Szwedo J., Ansorge J. 2015. The first Mimarachnidae (Hemiptera: Fulgoromorpha) from Lower Cretaceous lithographic limestones of the Sierra del Montsec in Spain // Cretaceous Res. Vol.52. P.390-401.

Zhang Q., Rasnitsyn A.P., Wang B., Zhang H. 2018. Myanmarinidae, a new family of basal Apocrita (Hymenoptera: Stephanoidea) from mid-Cretaceous Burmese amber // Cretaceous Res. Vol.81. P.86-92.

Zhang X., Ren D., Yao Y. 2017. A new species of Foveopsis Shcherbakov (Hemiptera: Fulgoromorpha: Fulgoroidea: Perforissidae) from mid-Cretaceous Burmese amber // Cretaceous Res. Vol.79. P.35-42. 